Article

\title{
Farm Models and Eco-Health of Poultry Production Clusters (PPCs) following Avian Influenza Epidemics in Thailand
}

\section{Worapol Aengwanich}

Stress and Oxidative Stress in Animal Research Unit, Faculty of Veterinary Sciences, Mahasarakham University, Maha Sarakham 44000, Thailand; E-Mail: worapol.a@msu.ac.th; Tel./Fax: +66-043-742-823

Received: 4 December 2013; in revised form: 6 April 2014 / Accepted: 9 April 2014 /

Published: 21 April 2014

\begin{abstract}
Thailand is located in Southeast Asia and is a country that was affected by highly pathogenic avian influenza (HPAI) epidemics during 2003-2004. Nevertheless, the Thai government's issuance policy of strict control and prevention of the disease has resulted in efficient disease control of avian influenza (AI). Poultry farmers have been both positively and negatively affected by this policy. There are three poultry cluster models worthy of attention in Thailand: (1) egg chicken poultry clusters over ponds; (2) egg chicken poultry clusters in coops raised from the ground and managed by a cooperative; and (3) poultry clusters in closed coops under contract with the private sector. Following the AI epidemics, additional poultry husbandry and biosecurity systems were developed, thereby generating income and improving the quality of life for poultry farmers. Nevertheless, raising large clusters of poultry in the same area results in disadvantages, particularly problems with both air and water pollution, depending upon the environments of each poultry model. Furthermore, the government's policy for controlling AI during epidemics has had a negative effect on the relationship between officials and farmers, due to poultry destruction measures.
\end{abstract}

Keywords: poultry production clusters; PPCs; eco-health; avian influenza (AI); Thailand

\section{Introduction}

Thailand's population is predominantly agricultural, and most people hold agricultural occupations involving both the cultivation of crops and animal husbandry for domestic consumers. During the period from the 1950 s to the 1970 s, the Thai government began to have a policy to produce food for 
export, and poultry products were one of the agricultural product types included in the production plans for export [1]. The aforementioned policy has had a tremendous impact on the nation's poultry farming, as poultry farmers have transitioned from raising poultry in their back yards to industrial poultry farming. Later on, the country's poultry industry experienced huge success [2]. Despite Thailand's high poultry production volume, $90 \%$ of the nation's poultry farmers continue to be small-scale farmers [3]. Most of Thailand's poultry farming is done in the country's central and eastern regions [4].

In 2003-2004, Thailand experienced avian influenza (AI) epidemics [5], and most of these occurred on farms with low biosecurity levels. These epidemics had a tremendous impact on poultry production and the living, health and socio-economic conditions of poultry farmers [4]. During the AI epidemics, the Thai government put in place disease control measures, such as stamping out, cleaning and disinfection, surveillance, movement control, campaigns for awareness promotion and panic reduction, improvement of biosecurity and restructuring of poultry production. These resulted in a continuous decline of AI outbreaks. The policy was implemented through four processes, namely quarantine, screening, zoning and compensation [4,6-12].

Burgos et al. [13] studied and classified poultry farming in Thailand into three systems. The first system was the traditional production system. The second system was the semi-industrial one. This type of system was quite large and connected with the commercial production system. The third system was the industrial system. Aengwanich et al. [14] defined domestic poultry production clusters (PPCs) as "areas of concentrated poultry production in rural areas usually separated from residential areas - where farms practice certain economies of scale and use comparative advantages of localities, resulting in improvements to and increased intensification of poultry production. The farms in the cluster apply standard biological safety and environmentally friendly practices and install related facilities. Major drives for the formation of PPCs and changes to PPCs include government programs for enhanced bio-security at both national and local levels, extended families, cooperatives and improved links to contracting companies that supply inputs and purchase outputs and outbreaks of highly pathogenic avian influenza".

The concept of eco-health, which focuses on the surrounding ecology, such as the physical environment, economic and social aspects and culture relating to health and the welfare of human beings [15], has played a key role in studies on the impact of the environment on human health. Nevertheless, following the AI epidemics in Thailand, socio-economic data on farming, including the various impacts of AI epidemics on poultry farming models, socio-economic characteristics, disease control and farming environments on small poultry cluster farms, became limited.

Therefore, the objective of the present study was to investigate the socio-economic farming characteristics, disease control and farming environments on small farms in PPCs following outbreaks of AI. The pool of knowledge gained from the present study will be of benefit in setting policies for the prevention and control of AI, improving the quality of life of poultry farmers and reducing problems with pollution in the environments surrounding poultry farms in the future. 


\section{Research Sites and Methodology Section}

\subsection{Research Sites}

The present study was conducted in three provinces in Thailand, namely, poultry clusters in Nong Khai, Nakhon Phanom and Maha Sarakham. Detailed descriptions of each area follow.

\subsubsection{Nong Khai Province}

Nong Khai province is located in the upper northeastern region. The area is narrow, stretching along the bank of the Mekong River with an approximate length of $210.6 \mathrm{~km}$. On the opposite bank of the Mekong River is Laos. Nong Khai has an area of $3027.280 \mathrm{~km}^{2}$. Its population is 509,870 , with a population density of 168.43 people $/ \mathrm{km}^{2}$. Nong Khai is $615 \mathrm{~km}$ away from Bangkok and $25 \mathrm{~km}$ from Vientiane, the capital city of Laos. In the Nong Khai province, the important poultry raised are layer chickens, and most of the farms are in three main districts, i.e., Muang district, Tha Bo district and Sri Chiang Mai district, with approximately 300 farms. The farming pattern is clusters of 30-100 farms that are located away from the communities, dispersed near natural water sources, e.g., large lakes or areas with irrigation systems and drainage systems, or on one's own land. A notable characteristic of the layer chicken production in Nong Khai province is that they keep fish with hens, building coops on fish ponds. The floor of the barn is built to leave holes to allow the feces of the chickens to fall into the ponds, serving as fish feed. The fish they keep are Nile tilapia and fish in the carp family. Thus, the farmers have two sources of income: from the layer chickens and from the fish.

\subsubsection{Nakhon Phanom Province}

Nakhon Phanom province is located in the upper northeastern region. Along the entire east frontier is the Mekong River. Nakhon Phanom is adjacent to Kham Muan province of Laos. Its area is $5512.668 \mathrm{~km}^{2}$. Its population is 704,768 , with a population density of 127.85 people $/ \mathrm{km}^{2}$. Nakhon Phanom is $740 \mathrm{~km}$ away from Bangkok. The poultry producer clusters in Nakhon Phanom are located in the Muang district. There is one cluster of 59 farm members. The distinct characteristic of the clusters is that they raise layer chickens in raised barns. The farmers' farms are on their own land. The cluster is managed as a cooperative group. The members jointly invest to provide factors of production from the outside. The farmers have been raising layer chickens in raised barns for over 20 years. The farmers mix the chicken feed with the material received from the cooperatives. The residential area, feed stock and preparation areas and the egg sorting barns are separated from the chicken barns.

\subsubsection{Maha Sarakham Province}

Maha Sarakham province is located in the center of the northeastern region. The province has an area of $5291.683 \mathrm{~km}^{2}$. Its population is 939,736 , with a population density of 177.59 people/ $\mathrm{km}^{2}$. Maha Sarakham is $407 \mathrm{~km}$ away from Bangkok. The poultry production cluster in Maha Sarakham is in Kosumphisai district, which is adjacent to Khon Kaen province. The distinct characteristic of the farms is that they are situated along the road to the community, with no farms in the community. 
The farms are closed systems. There are approximately 50 farms in total, most of which keep broilers and female and male layer chickens. The farmers have contracts with private companies and manage their farm as per distinctive agreements. The farmers raise chicken in an evaporative cooling system. Every farm in this system has to be approved for farm standards by the Department of Livestock Development (DLD). The biosecurity system levels are high.

\subsection{Methodology}

This study was a qualitative survey performed during January-August, 2012, after a highly pathogenic avian influenza (HPAI) outbreak in Thailand (the last outbreak of HPAI in Thailand was reported in 2006). The project was approved by the institutional review board (IRB). Data collection was conducted in the three groups of PPC, i.e., farmers who raise poultry over fish ponds in Nong Khai (farmers in this province are small producers and the biosecurity level of poultry farms is low), farmers who raise poultry in the form of cooperatives in Nakhon Phanom (the biosecurity level of poultry farms in this province is medium) and farmers who raise poultry under contract with private companies in Maha Sarakham (all farms were approved for the biosecurity level (high level) by the DLD in Thailand; the details of the biosecurity evaluation are shown in Table 1), in terms of attitudes and behaviors and economic, social, biodiversity, human health, environmental and biosecurity aspects. Data were collected from poultry farmers in the three provinces, amounting to a total of 50 families per province by a structural questionnaire. After that, the researcher conducted interviews with people involved in the PPC in each province, i.e., poultry farmer group leaders, community leaders, sub-district organization administration officials and district and provincial livestock office officials. The researcher also collected data through participative observation of the poultry farmers to conduct an in-depth analysis of the case studies. Next, the data collected were used in focus group discussions to verify the data among the people involved and to conclude the study.

Table 1. The biosecurity level of poultry production clusters (PPCs) in Nong Khai, Nakhon Phanom and Maha Sarakham province, Thailand.

\begin{tabular}{|c|c|c|c|c|}
\hline Items & Indicators & NK & NP & MS \\
\hline \multirow[t]{5}{*}{$\begin{array}{l}\text { 1. Components } \\
\text { of farm }\end{array}$} & 1.1. Location & & & \\
\hline & $\begin{array}{l}\text { 1.1.1. Farm is located in an environment with a } \\
\text { minimal risk from any contamination of physical, } \\
\text { chemical and biological hazards. }\end{array}$ & - & - & + \\
\hline & 1.2. Layout & & & \\
\hline & $\begin{array}{l}\text { 1.2.1. Farm shall have a sufficient size, suitable for } \\
\text { rearing, and does not pose any problem to } \\
\text { the environment. }\end{array}$ & - & - & + \\
\hline & $\begin{array}{l}\text { 1.2.2. The layout of the farm shall be orderly, } \\
\text { separated according to farm activities, such as } \\
\text { rearing, feed storage, equipment storage, carcass } \\
\text { disposal, worker accommodation, egg storage room. }\end{array}$ & + & + & + \\
\hline
\end{tabular}


Table 1. Cont.

\begin{tabular}{|c|c|c|c|c|}
\hline Items & Indicators & NK & NP & MS \\
\hline & 1.3. Housing & & & \\
\hline & $\begin{array}{l}\text { 1.3.1. House shall be strong, hygienic, easily cleaned } \\
\text { and maintained and well ventilated. }\end{array}$ & - & + & + \\
\hline & $\begin{array}{l}\text { 1.3.2. The area in the layer house is adequate for } \\
\text { hygienic chicken rearing. }\end{array}$ & - & + & + \\
\hline \multirow[t]{3}{*}{ 2. Feed } & $\begin{array}{l}\text { 2.1. Feed quality shall comply with the feed quality } \\
\text { control act, relevant laws and regulations. }\end{array}$ & + & - & + \\
\hline & 2.2. All layers can access feed. & + & + & + \\
\hline & $\begin{array}{l}\text { 2.3. Feed shall be stored in an area to prevent } \\
\text { contamination and deterioration. }\end{array}$ & + & + & + \\
\hline \multirow[t]{3}{*}{ 3. Watering } & $\begin{array}{l}\text { 3.1. The water source shall be located in an area safe } \\
\text { from the contamination of hazardous substances. }\end{array}$ & - & + & + \\
\hline & 3.2. The water used shall be cleaned. & - & + & + \\
\hline & 3.3. All layers can access water. & + & + & + \\
\hline \multirow[t]{11}{*}{$\begin{array}{l}\text { 4. Farm } \\
\text { management }\end{array}$} & 4.1. Farm management manual & & & \\
\hline & $\begin{array}{l}\text { 4.1.1. The availability of a manual demonstrating the } \\
\text { details of the important farm operations, e.g., rearing } \\
\text { system, recording system, animal welfare and health } \\
\text { management. }\end{array}$ & + & + & + \\
\hline & 4.2. Personnel & & & \\
\hline & $\begin{array}{l}\text { 4.2.1. The operator who takes care of layer rearing } \\
\text { shall be skillful and trained. }\end{array}$ & $\mathrm{ST}$ & $\mathrm{ST}$ & + \\
\hline & $\begin{array}{l}\text { 4.2.2. The availability of licensed veterinarian to } \\
\text { supervise the layer farm and animal health. }\end{array}$ & - & - & + \\
\hline & 4.3. Cleaning and maintenance & & & \\
\hline & $\begin{array}{l}\text { 4.3.1. House and equipment shall be cleaned and } \\
\text { maintained in a good and hygienic manner. }\end{array}$ & ST & $\mathrm{ST}$ & + \\
\hline & $\begin{array}{l}\text { 4.3.2. Cleaning and disinfection of the house and } \\
\text { equipment shall be done after all layers have been } \\
\text { removed; and its effectiveness can be examined by } \\
\text { swabbing the chicken rearing area for microbial } \\
\text { culture. The house shall be vacated according to the } \\
\text { notification of the Department of Livestock } \\
\text { Development (DLD). }\end{array}$ & + & + & + \\
\hline & $\begin{array}{l}\text { 4.3.3. House litter and nest box litter materials shall } \\
\text { be clean and dry. }\end{array}$ & ST & $\mathrm{ST}$ & + \\
\hline & 4.4. Egg management & & & \\
\hline & $\begin{array}{l}\text { 4.4.1. The availability of hygienic cleaning and } \\
\text { handling of eggs to be properly collected and stored. }\end{array}$ & - & $\mathrm{ST}$ & + \\
\hline
\end{tabular}


Table 1. Cont.

\begin{tabular}{|c|c|c|c|c|}
\hline Items & Indicators & NK & NP & MS \\
\hline \multirow[t]{7}{*}{ 5. Animal health } & 5.1. Disease prevention and control & & & \\
\hline & $\begin{array}{l}\text { 5.1.1. Prevention and disinfection of pathogens for } \\
\text { vehicles, equipment and personnel shall be provided } \\
\text { before entering into the farm, including the record of } \\
\text { entry and exit for inspection. }\end{array}$ & ST & ST & + \\
\hline & $\begin{array}{l}\text { 5.1.2. A disease surveillance program shall be } \\
\text { provided in order to effectively control } \\
\text { and eradicate the disease. }\end{array}$ & ST & ST & + \\
\hline & $\begin{array}{l}\text { 5.1.3. Randomly check the immunity to the major } \\
\text { disease to monitor the current immunity status and to } \\
\text { make use of such information for an appropriate } \\
\text { disease prevention plan. }\end{array}$ & + & + & + \\
\hline & $\begin{array}{l}\text { 5.1.4. If there is an outbreak or suspicion of disease } \\
\text { outbreak, follow the practices complying with the } \\
\text { laws and regulations on animal epidemic disease and } \\
\text { the recommendation of the DLD. }\end{array}$ & - & + & + \\
\hline & 5.2. Treatment & & & \\
\hline & $\begin{array}{l}\text { 5.2.1. Recommended treatments by the farm } \\
\text { veterinarian shall be followed. }\end{array}$ & - & - & + \\
\hline $\begin{array}{l}\text { 6. Animal } \\
\text { welfare }\end{array}$ & $\begin{array}{l}\text { Care shall be taken for the welfare of the animals. In } \\
\text { cases of injury, sickness or deformity, layers shall be } \\
\text { appropriately treated to avoid suffering. }\end{array}$ & - & + & + \\
\hline 7. Environment & $\begin{array}{l}\text { Appropriate disposal of refuse and waste, such as } \\
\text { manure and discarded carcasses, shall be practiced, } \\
\text { including waste management surrounding the house, } \\
\text { to prevent odor and pathogens. }\end{array}$ & - & + & + \\
\hline \multirow[t]{2}{*}{$\begin{array}{l}\text { 8. Record } \\
\text { keeping }\end{array}$} & $\begin{array}{l}\text { 8.1. Important operations in farm management that } \\
\text { affect animal health and disease control shall } \\
\text { be recorded. }\end{array}$ & - & + & + \\
\hline & $\begin{array}{l}\text { 8.2. Records shall be kept for at least } 3 \text { years } \\
\text { for inspection. }\end{array}$ & - & - & + \\
\hline $\begin{array}{l}\text { Level of } \\
\text { Biosecurity }\end{array}$ & & Low & Medium & High \\
\hline
\end{tabular}

Remarks: (1) NK = Nong Khai; NP = Nakhon Phanom; MK = Maha Sarakham; (2) ST= sometimes; -- does not meet DLD standard; += does meet DLD standard; (3) the indicators for biosecurity evaluation were adapted from National Bureau of Agricultural Commodity and Food Standards [16].

\section{Results and Discussion}

Data on social attitudes and behaviors and economic, biodiversity, human health, environmental, and biosecurity aspects obtained from the three groups of poultry farmers, i.e., the group raising poultry over fish ponds in Nong Khai, the cooperative poultry group of Nakhon Phanom and the PPC under contract with private companies in Maha Sarakham, are described below. 


\subsection{Economic Aspects}

\subsubsection{PPC in Nong Khai}

The PPC in Nong Khai raised 500-2400 chickens/farm. The case studies revealed that the income from poultry constituted $80.65 \%$ of the total household income. Most workers in the production were family members, except for some families with many coops, who had to hire migrant workers from a neighboring country (Lao PDR (People's Democratic Republic)). The farms with a small number of chickens did not hire any employees unless it was necessary. On average, members from the PPC in Nong Khai province took out a loan from the Bank for Agriculture and Agricultural Co-operatives at $360,000 \mathrm{baht} /$ family and had a debt of 320,000 baht/family. Groups of layer chicken farmers in Nong Khai province sold eggs to local middlemen. The eggs produced from the cluster were sold to the middlemen in Nong Khai or nearby provinces, such as Udon Thani, Nong Bua Lamphu and Loei, and the retired hens were sold in the markets and the local slaughterhouse. All transactions were made in cash. Feed, chemical supplies and chicks were provided by local stores. The stores granted credit to the farmers, and there were officers from the DLD training the farmers about disease control.

\subsubsection{PPC in Nakhon Phanom}

The PPC in Nakhon Phanom raised an average of 5000 chickens/household. There were three sources of income for the PPC of Nakhon Phanom province, from selling eggs, chicken manure and retired chickens. The main workers were family members (husband and wife) and other members, e.g., children and in-laws. There were no permanently hired workers. Sometimes, workers were hired for loading chicken manure for sale or some specific tasks, e.g., chicken catching or vaccination. Farmers were paid for the disinfectant and boots, which cost approximately 2000 baht/year. Farmers in this PPC borrowed from the Bank for Agriculture and Agricultural Co-operatives. Debts of 50,000-90,000 baht/household were mostly from feed and medical suppliers for raising chickens. Farmers sold eggs to communities around the cluster and middlemen from the district or nearby provinces. The PPC partnered with a private company that sold food, drugs and medical supplies to the cooperative. The cooperative's members ordered materials from the cluster's center to serve as ingredients for feed or to prevent and control diseases in their farms.

\subsubsection{PPC in Maha Sarakham}

The chickens raised in the PPC in Maha Sarakham were broilers and male and female layer chickens. Each farm had one barn that could accommodate 21,000-28,000 chickens. Female layer chickens could be reared twice per year. Male layer chickens could be reared 3-4 times per year. Poultry farmers made contracts with Sri Viroj and Betagro Company in the form of a contract farming system. Income for the poultry production of farmers in Maha Sarakham province was derived from male and female layer chickens; the average income of each farm was 330,000 baht/year. The average income of farmers came from selling chickens back to the companies, rice farming and sugar cane farming. The workers at the farms were mainly family members. The main labor was from the husband, wife and their children. The number of workers in each family was 2-4 people. There were no hired 
workers, except for some tasks, e.g., when farmers needed to remove chicken manure, members from the community were hired occasionally, and when it was time to sell chickens, workers from other farms (relatives' farms) were asked to help. Villagers were hired to scoop chicken manure for sale.

At the beginning, farmers built the bathroom, changing room and food storage facilities, bought equipment for disinfectant spraying and boots and fenced the farm. The initial cost was approximately 50,000 baht. The housing was built with a bank loan; afterward, biosecurity measures were put in place. Private companies invested in chicks, feed, drugs, medical supplies, chemicals, veterinary services and other factors of production. The farmers knew only the cost of housing and workers. The other costs were handled by the private companies and were unknown to the farmers. When the chickens gained enough weight, the private companies would come to catch them for weighing and pay the money due to the farmers. Therefore, the farmers did not know the actual cost of the chickens, as they received only the money from farming.

Most farmers borrowed money from the Bank for Agriculture and Agricultural Co-operatives. Each family took out a loan of approximately 300,000-400,000 baht to invest in housing and biosecurity measures. At the time of the study, each farmer had a debt of 100,000-400,000 baht/farm, depending on the loan and payment period.

The PPC in Maha Sarakham did not have any issues with marketing, as they were contract farmers with private companies. The companies bought chickens at the promised rate upon which they had agreed. When it was time, the farmers would sell chickens back to the company.

The positive and negative economic impacts of PPCs on poultry farmers were as follows:

(a) Positive economic impact of PPCs on farmers.

As the measure on poultry production clustering was announced, the obvious positive impact was the control of disease outbreaks within farms, which resulted in an improvement in poultry health. Mortality during poultry rearing decreased, due to more stringent prevention and eradication of disease within the farms. Farmers thus obtained higher poultry productivity. However, this depended on the price of the product at any one time, except in the case of contract poultry farming, in which the income of farmers per unit of output remained constant, and farmers earned more when the productivity was increased or poultry mortality was reduced.

(b) Negative economic impacts of PPCs on farmers.

Higher production costs on housing, the biosecurity system and development toward the adoption of a standard farming system were additional fundamental costs the farmers had to absorb, whereby a loan needed to be obtained from a bank through the use of their own land as a loan guarantee, except in the case where they already had adequate operating capital.

\subsection{Social Aspects}

\subsubsection{PPC in Nong Khai}

For the poultry farming society in Nong Khai at the family level, the labor division among family members was as follows: the father fed and gave water to the chickens, tended the chickens, vaccinated the chickens and gave them medicines, collected eggs, mowed the grass, took care of the 
fish farming, sold eggs and attended meetings arranged by the DLD; the mother collected and sold eggs, counted the money and did the accounting, placed orders and made payments, helped with the vaccination of chickens, cooked, took care of the children and planted trees; employees (on some farms) helped the father.

The PPC in Nong Khai had continuously undergone economic and social changes, both before and after the AI outbreak, e.g., the economic status of the farmers of Khok Pla Faang village used to be good, and the farmers had better income from chicken farming than from tobacco cultivation. Every family was happy and helpful to others in the village. There were informal talks among the group members, and they could consult with one another as kinsmen, especially about the costs of the factors of production, disease epidemics and chicken husbandry. After the AI outbreak, the economics worsened, and many farms ceased to operate.

The situation was similar with farmers from the layer chicken production cluster in Wieng Khook village. The economics of the cluster were good with many chicken farms in the cluster before the outbreak. After the AI outbreak, the number of farms declined as the price of eggs lowered, whereas the cost soared. The cluster faced problems, and some farms had to close: Khok Pla Faang village was left with only nine farms. Abandoning the chicken farms, some of the farmers continued with tobacco cultivation or other careers, and only fish ponds were left. However, the economics of layer chicken production were considerably better at the time of the study.

Generally, the relationships between farms in Nong Khai province were within the cluster. Most of these were relationships among relatives and a loose relationship between farmers who bought the factors of production from the same store. The latter kind of relationship was loose, with interactions, such as checking the prices of products or a talk at a training session/seminar held by stores or at a meeting arranged by the Provincial Livestock Office. There was not much cooperation among the producers. They checked the prices of feed or how to tend their livestock. In contrast, at the poultry farms in Tha Samraan village, as most farmers were relatives, they usually consulted and helped one another, including providing occasional financial support. Finally, the relationships within the cluster became colder, due to the more demanding work and internal competitiveness. It was obvious that the AI outbreak had severe economic effects on the layer chicken production in this province. Even after the recovery and the measures taken, the economics of farmers had improved, but the relationships within the cluster showed a tendency to worsen.

\subsubsection{PPC in Nakhon Phanom}

The PPC of Nakhon Phanom divided work within the families as follows: the farm owner (male) mixed feed, fed, gave water to and vaccinated the chickens and collected the eggs; his wife sorted and collected the eggs, tended the coops and gave water to the chickens. When more workers were needed, e.g., for vaccination, the entire family would be at work.

The layer chicken production cluster at Nakhon Phanom was a group of farmers in a large community that had been raising layer chickens for almost 20 years. During the first phase, the cluster was bound to the local capitalists for credits for feed, drugs and medical supplies for raising chicken. As they had been in debt from continual farming after the AI outbreak in the year 2006 (some farmers stopped farming then), the farmers grouped to buy feed, chicken breeds and medical supplies, each 
investing 20,000-50,000 baht. There were occasional group meetings. As their farms were in close proximity, the farmers always consulted with one another.

The PPC in Nakhon Phanom received financial support in forming the cluster from the province via the Livestock Office of Nakhon Phanom province. The farms had no relationships outside the group, except with private companies that provided feed, drugs and medical supplies for internal use.

The farming of the production cluster of Nakhon Phanom province was cooperative. A board of directors was founded and there was investment in the form of stocks for providing factors of production and joint prevention and control of diseases within the community, e.g., disinfectant spraying in the streets and the area of the community. There were meetings among cooperative members to set measures and to plan operations and solve problems within the cluster.

\subsubsection{PPC in Maha Sarakham}

Regarding domestic social relationships, the labor division in the PPC in Maha Sarakham was as follows: the husband brought the feed into the housing; together, the wife and children fed the chickens, spread the manure in the housing, gave water to the chickens, removed the manure and cleaned the housing. The wife also took care of housework.

For inter-farm relationships within the cluster, the chicken farming of the PPC in Maha Sarakham was initiated by the family "Donlakhorn". This was because the cost of building chicken housing and of running a closed system was high. Later, they supported their relatives and extended family farms. Meanwhile, worthy activities (such as donations to the temple or charity) in the community went on as before. Consultation in the cluster was about environmental issues or problems from raising chicken, e.g., fly elimination or smell removal among clusters in the same networking company once or twice a year. Most of the cooperation of the farmers in the cluster was to solve issues, such as the ammoniac smell and flies in the community when there were complaints. The issues were solved by drying the manure, selling some to other communities as fish food and using fly repellent. However, they did not associate with farms in other networking companies, even if they were relatives.

\subsection{Attitudes and Behaviors}

\subsubsection{PPC in Nong Khai}

From the past to the present, all poultry houses have been built above fish ponds, because the aforementioned format enables farmers to have multiple sources of income from the sale of eggs, retired hens and fish. Thus, the farmers maintain the aforementioned format, because they deem it suitable for their families. The system of chicken housing on fish ponds in Nong Khai province reduces the ammoniac smell and flies, yet the problems found were that some farms were run with an inappropriate rate of fish, layer chickens and size of fish ponds. Thus, the water became foul, as in the case of Tha Samraan village, where the fish ponds had not been let dry, the fish died and the water became foul from an excessive amount of chicken manure. In terms of general consumption among poultry production farmers in Nong Khai, there was poultry and egg consumption, as per local culture.

In contrast, disease control in the PPC in Nong Khai province was not strict. Only some farms followed a strict and correct method for disease control and treatment. Most of them focused on these 
only during the epidemic. The required practice was proper vaccination, dipping egg packs and feet (for some farms) in disinfectant, the spraying of disinfectant, disinfecting the barn, prohibiting outsiders from entering the farms (this might have been controlled more strictly during the outbreak), treating chickens with antibiotics and vitamins, removing infected chicken for treatment when found and consulting with other clusters when an outbreak occurred (mostly, treatment would be given only after the disease was found). There was no warning system. Sometimes, the farmers learned from the drug seller about outbreaks in other districts, as each farm bought drugs from the store in the network.

\subsubsection{PPC in Nakhon Phanom}

In general, farmers in the PPC in Nakhon Phanom consumed eggs and cooked retired layer chickens, according the consumption culture in the community. The farmers raised chickens in raised poultry houses, due to limited land and the fact that the people in this province refused to consume fish fed chicken manure. Although certain farms also raised fish, fish sales were faced with a problem of acceptance by people. In terms of disease control, the disease control system for every farm in the cluster was as follows: separating feed and the egg sorting barn; keeping visit records; applying a proper disease control system; using disinfectant pools; changing clothes and shoes before entering the coops; the control of vehicles entering the farm; fencing the farm area; and weekly disinfection of the farm when the weather changed.

\subsubsection{PPC in Maha Sarakham}

The customary culture of the PPC in Maha Sarakham is the consumption of indigenous chickens and ducks, with various poultry cooking methods, including roasting, boiling, stewing and making a spicy minced meat salad. Sometimes, they eat the poultry produced in the farming system, but not so often.

In the community that was separate from the cluster, fighting cocks, indigenous chickens and ducks were kept. In the PPC, the male and female layer chickens were reared in a closed system. Even though the farmers in Maha Sarakham province raised chickens in a modern closed system, they still held onto some traditional chicken raising practices, e.g., giving boiled Andrographis or Tinospora crispa to chickens to cure the flu.

Farms in Maha Sarakham had a good biosecurity system, i.e., at the gate at the farm entrance, before entering the barn, the farmers would shower, change their clothes and spray; the residential zone and the housing were separate. There was a storage room for materials, and chickens were reared in a closed system. When any chicken became sick, the farmer would inform the company, and the company would send their staff or veterinarians to treat the chicken, giving it drugs, vitamins and vaccines. Flies and smells were controlled by spraying chemicals onto the bedding. The farmers removed chicken manure from the barn and sold it to buyers.

\subsection{Biodiversity Aspects}

According to the data on the biodiversity of poultry raised in Nong Khai, Nakhon Phanom and Maha Sarakham, the PPC in Nong Khai mainly raised layer chickens, but some farms also kept 
indigenous breeds, ducks and turkeys. Among the exotic breeds found in the PCC were teals, white egrets, other exotic breeds and some local birds. In Nakhon Phanom, the PPC only kept layer chickens. In addition, there were also a few migratory birds and some local birds, as there were trees all around the farms. Poultry breeds found in the PPC in Maha Sarakham were layers, male layers, broilers, indigenous chickens and ducks. A few migratory birds and some local birds were also found, as there were trees all around the farm.

\subsection{Human and Animal Health Aspects}

As the biosecurity aspect of the disease control measures was in place and strictly implemented by the farmers in the PPCs, e.g., appropriate housing improvement, preventing animals from entering the poultry houses, farm entry and exit control, disinfection, the appropriate practices of workers, the appropriate disposal of the remains of dead and sick animals, medication, etc., it was found that the incidences of poultry sickness or death in the farms with strict biosecurity control were reduced significantly. Animal health was improved, and infections in poultry were reduced. Meanwhile, with regard to the health of farmers, the government had a policy for farmers in PPCs, such as those in Nong Khai and Maha Sarakham, to receive a medical examination and influenza vaccination on an annual basis. This was considered a regular health practice for the monitoring and care of farmers.

\subsection{Environmental Aspects}

As PPCs took shape, this meant a collection of a large number of poultry farms in one area, from which environmental impacts arose. The size of the impact depended on the management and control of the contamination of the waste that spread from the farms into the environment, e.g., poultry droppings, ammonia odors developing from accumulated droppings, dust diffusion and a large number of flies in certain seasons. The management of environmental problems in various areas differed based on farming types, housing styles, land characteristics, waste disposal systems, etc.

Examples of the management of environmental and pollution issues among the farms in the PPCs were as follows:

(a) Case study of PPC in Nong Khai

The type of farming of layer chicken production clusters in Nong Khai had the unique characteristic that layer houses were built on top of a fish pond, whereby layer chicken droppings fell into the pond and became fish feed. As a result, there was no problem of ammonic odors due to the accumulation of droppings. There were neither flies nor mosquitoes in the farms. As the fish in the pond grew and reached the required weight, however, the water had to be pumped out and released into natural waterways. The water being pumped out contained much organic matter, which gave rise to an impact on the water sources; the impact depended on the volume of the water and the organic matter being released. This farming type, however, did not cause odor problems due to poultry droppings for the surrounding communities. 
(b) Case study of PPC in Nakhon Phanom

The rearing of layer chickens in the Nakhon Phanom PPC was done in raised floor housing, where chicken droppings fell onto the ground underneath. After a period of accumulation, absorbing much moisture or becoming wet from rain, ammonia gas developed in a high volume and affected the environment within the farm, the farmers and the neighbors. During certain periods of time, there were also a large number of flies, which caused much annoyance. Farms that employed good disposal methods for chicken droppings did not face the aforementioned problems; on the other hand, if the management was not appropriate, the farmers were often involved in a dispute with community inhabitants.

(c) Case study of PPC in Maha Sarakham

The PPC in Maha Sarakham reared male and female layer chickens and broilers in closed housing with an evaporative cooling system. Therefore, the problems of dust, flies and odor were considerably small, except where rearing density was high and moisture within the poultry houses was also high, due to inappropriate water management. The accumulation of poultry droppings emitted very bad odors. When odorous air circulated outside, it caused air pollution and problems with neighboring farms. However, as the cluster was distant from the communities, the problem was not severe. Moreover, sub-district administration organizations also enforced legislation controlling the construction of poultry houses where farmers wishing to set up a farm had to obtain the consent of the owner of neighboring pieces of land before the construction could proceed. This lessened the problem of odor in communities.

\subsection{Biosecurity Aspects}

During the outbreaks of AI, the Thai government issued various disease control and prevention policies that called for more stringent biosecurity management in poultry farms at all levels. However, after the outbreaks ended, the biosecurity control of certain PPCs relaxed, due to the high investment and complicated procedures. Most farmers in the clusters tended to apply the strict control measures during outbreaks of poultry diseases in their vicinity, such as the PPC in Nong Khai. On the contrary, the biosecurity control system of the PPC in Nakhon Phanom remained in place and was strictly followed by the farmers, because the government authorities had regularly promoted and given advice on farming practices, assessed compliance with farming standards and applied appropriate control strategies, which resulted in strict compliance with the government measures. The PPC in a contract farming system in Maha Sarakham also had the biosecurity system in place, and it was strictly implemented, as all farms had to achieve the farming standard certification, which was one of the conditions of the contracts made with large private companies. All farmers had to be certified, and this resulted in their high standard of disease prevention.

\subsection{Relationship between Officials and Poultry Farmers in PPCs}

During AI epidemics, the government had a policy for the prevention and control of AI with a number of measures, such as stamping out, cleaning and disinfection, surveillance, movement control, the improvement of biosecurity and the restructuring of poultry production. This policy, particularly 
the destruction of poultry within a 5-km radius of outbreaks of the disease, resulted in tensions in the relationship between officials and poultry farmers, with the poor relationship on a continual decline. Farmers did not dare to report data, because they were afraid the officials would come and destroy the poultry they raised on their farms if they did. Therefore, the aforementioned reasons are indicators of another impact of the policies for the prevention of AI outbreaks, particularly concerning stamping out measures. In other words, the gap between officials and poultry farmers widened.

After the policy to control the spread of AI was announced in Thailand, the DLD, on behalf of the government, issued a disease control notification and instructed all provincial livestock offices to abide by the measures of which they were notified, whereby all poultry farms had to implement the measures to prevent and control disease. As a result of AI outbreaks, farmers were required to adopt the farming standard that called for standardized disease prevention and control. For those groups of poultry farmers who had already formed a cluster, e.g., the PPC in Nong Khai, the provincial livestock office promoted and encouraged farmers to increase the biosecurity level of each layer chicken farm. Activities included the improvement of poultry housing sanitation, the installation of netting around the housing, the implementation of a system for preventing pathogens from entering the farm, such as showering, wearing boots and changing clothes, the installation of fencing to prevent outsiders from entering the farm and the control of transportation.

In the case of the PPC in Nakhon Phanom, the farmers had changed from traditional rearing to a common form of farming that was a cooperative group and upgraded their farms to standard poultry farms, which had to be certified by the DLD, with a focus on the improvement of housing and the implementation of biosecurity and environmental systems. Farmers had to invest in such improvements by themselves, on top of the original investment made to develop the PPC system in accordance with government policy.

The PPC in Maha Sarakham was the group where changes in the grouping pattern of poultry farmers had been clear-cut based on the government AI outbreak control policy: before the AI outbreaks, farmers used to rear poultry, such as broilers, under contract with large private companies, such as Charoen Pokphand (CP) affiliates, whereby a semi-intensive farming system was implemented. After the AI outbreaks, other large private companies approached with a new farming system by encouraging the clustering of layer chicken farms, in which 30-40 chicken farms were located in the same area. Farmers had to invest in housing by obtaining a bank loan to construct the closed system housing and to apply for farm standard certification from the DLD. The farming system changed from a guaranteed price system to a hired farming system, such as in the case of layer chicken farming to raise and deliver pullets to the company that was a party to the contract, whereby the company would supply the farmers with such production inputs as chicks, feed, chemicals, biological products, e.g., vaccines, as well as pay electricity bills for the closed system operation. When the contract term was due, the company would repay the wage and rental charge for the housing and cages.

As a result of the change to comply with the AI control policy, the direct economic impact on poultry farmers was the investment in a new farming system, which might include the improvement of housing, the rearing system, the biosecurity system, etc. In the case where the farmers did not have adequate funds to continue their operation after being affected by multiple measures of the government during AI outbreaks, some had to discontinue farming, due to the lack of funds for ongoing operation and/or for upgrading the farming system to the level required by the government policy. 
The Thai social structure comprised the communities and the people therein who were related through the kinship system, as every member of a family needed to share the use of land resources, which had been shared from generation to generation. As the community structure changed, joint decisions within the family or community were usually required, as could be seen from the Nong Khai PPC, where groups of poultry farmers mainly developed in the form of extended family farms. However, the encouragement to restructure the grouping other than as kinship groups usually arose from external factors, such as government support. This form of social relationship, on the other hand, was still based on kinship systems. An example is the setup of the poultry production cooperative in Nakhon Phanom: although this was a social group established through government support, it was based on the kinship system and the relationships among neighbors in the same community.

When analyzing the overall characteristics of PPCs in Thailand, however, it was found that in the setup of the clusters, each farm was located on its own land, except in the case of compartment-type farming, where large private companies bought the land and set up farms of their own. The administrative activities of farmers in PPCs were therefore complete in their own farms and were commercially independent of neighboring farms. This might be different from China or Vietnam, where the government arranged production inputs, such as land, which made it possible to gather a group of farmers to form a production cluster in the same area.

In general, the poultry production methods of Thai farmers involve back yard poultry production with no technology or a planned poultry production model, particularly with small farmers in rural areas. Hence, the poultry production of farmers is only a supplemental occupation or food source. Back yard poultry production began to transform into poultry production for sale or commercial purposes, but knowledge about strict or intensive poultry production relied on new knowledge and technology, including strict disease prevention and control. Consequently, the poultry farmers either did not understand or were unable to practice the aforementioned measures. Therefore, when poor disease control was practiced on the farms, outbreaks of disease occurred at those farms on a regular basis and resulted in disadvantages for the poultry farmers as more chickens became ill and income decreased. In addition, because the farmers had no understanding of the importance of preventing and controlling disease, they had few ideas about developing or improving biosecurity systems. Hence, when there were outbreaks of AI in Thailand in 2003-2004, even though the government had a policy in place for poultry farms to develop biosecurity systems that the poultry farms had to follow (in the early stages, farmers went along with the policy), farmers' adherence to the policy for preventing and controlling the disease eased when there were fewer AI outbreaks. Therefore, measures for instruction, building correct understanding and adjusting attitudes and behaviors are essential in developing disease prevention and control on poultry farms.

Former poultry production models in PPCs in the province of Nong Khai involved raising chickens in pens raised high above the ground. Later on, however, poultry production methods involved experiments with raising chickens over fish ponds, which yielded positive results, with increased income from the fish. Moreover, the people in this province accept and consume fish fed chicken excrement as the main food source. Therefore, poultry production models for egg-laying chickens in Nong Khai are all based on the same design, which differs from Nakhon Phanom, where most people do not consume fish fed chicken excrement; hence, the fish raised by this method are usually unsellable. 
Therefore, the only poultry production method in the province of Nakhon Phanom involves raising poultry in pens raised above the ground.

Nevertheless, although poultry farmers were found to raise chickens with more modern systems in the case of the PPC in the province of Nakhon Phanom, farmers were still found to use former ideologies in raising chickens, such as using herbs to treat sick chickens, which indicated that communities possessed original knowledge and continued to believe in the use of former practices in raising chickens in combination with poultry production for commercial purposes or based on modern methods, because herbal methods continued to yield good outcomes.

In terms of biosecurity, the findings indicated that raising large numbers of birds on the same farm put the farm at high risk for outbreaks of disease. Poultry farms raising poultry by modern methods raised only one type of poultry on the farm. According to the findings of the present study, the PPC in Nong Khai raised other types of poultry, such as ducks, geese or turkeys, in addition to egg-laying chickens on the same farm, while clusters of farmers raising egg-laying chickens in Nakhon Phanom raised only one breed of egg-laying chickens. The same was true with the PPC in Maha Sarakham. Therefore, the PPC in Nong Khai was at a higher risk for outbreaks of disease than PPCs in Nakhon Phanom and Maha Sarakham.

According to the policy for increasing biosecurity systems on poultry farms, more biosecurity systems have been employed on poultry farms. Wei and Aengwanich [17] conducted a study on biosecurity systems by employing an evaluation form and found that biosecurity systems for PPCs in Maha Sarakham, which had been accredited by the DLD, were of higher quality than those in Nong Khai and Nakhon Phanom. Furthermore, the increase in biosecurity systems on the farms reduced the number of poultry deaths in the PPCs in Maha Sarakham and made the number of poultry deaths lower than that in Nong Khai and Nakhon Phanom. In addition, because AI is a disease of epidemic proportions among animals that spreads from animals to humans, the government also has a policy for controlling and preventing the disease in humans [11]. Therefore, farmers whose work involves exposure to poultry and officials receive health check-ups. Moreover, these poultry farmers are vaccinated against influenza annually in order to help them build immunity against the disease.

Poultry farms generally encounter air environmental issues, due to fermented chicken excrement and the accumulation of ammonia gas in large amounts. The aforementioned gas has the effect of irritating the eyes and respiratory tracts of poultry farmers/workers. Furthermore, exposure to the gas can cause respiratory diseases [18-20]. According to the findings of the present study, the farms in the PPC in Maha Sarakham where chickens were raised in closed systems experienced problems with polluted air, particularly concerning accumulated ammonia gas in the chicken pens. In addition, farms in the PPC in Nakhon Phanom were found to have the same problems. Therefore, it is evident that the ecosystems of the PPCs are constantly confronted with air pollution issues. Hence, measures need to be developed to solve the problem of disposing of large amounts of waste on the farms and solving excrement fermentation problems that lead to odors, such as water dripping over the excrement due to broken watering equipment or leaky roofs during the rainy season, etc.

Nevertheless, the aforementioned problems were not encountered on the farms of poultry farmers in the PPC in Nong Khai, where chickens were raised over fish ponds. When the chickens excreted waste, it fell into the ponds and became fish food. Hence, the problem of odor was reduced or eliminated altogether. However, in cases where the chickens excreted waste into the pond in large 
amounts, but the pond size and number of fish were disproportionate, problems occurred with wastewater in the ponds. Additionally, when the fish grew to the size where they could be caught and sold, farmers released the water from the ponds into public water sources, which resulted in problems with polluted water sources in communities and conflicts between farm owners and community residents. Therefore, problem-solving methods should involve adjustments in the ratio of the number of chickens raised to ensure that it is proportionate to the pond size and the number of fish released into the ponds. Otherwise, the amount of oxygen might be increased in the water sources by using proper equipment.

Biosecurity systems are systems that help prevent diseases from invading farms. According to the findings of the present study, the PPC in each cluster model had a different biosecurity system. In the early days following the policy for disease control on farms in PPCs, the PPC farmers in Nong Khai practiced compliance with government policy. Then, when the outbreaks of the disease had died down, the stringency in adhering to disease control activities gradually declined, while the PPC in Nakhon Phanom continued to practice disease control activities and biosecurity systems, because the DLD officials continued to visit, offering supervision and support of the cluster activities. The two aforementioned phenomena are indications that officials play an important role in assisting farmers in PPCs to realize the importance of disease prevention or biosecurity systems on farms, while the poultry farmers in the PPC in Maha Sarakham required accreditation for compliance with farming standards in strict disease control before they could sign contracts with private sector companies. Hence, the biosecurity systems on these farms were more advanced than those on the farms in PPCs in Nong Khai and Nakhon Phanom. Therefore, it is evident that government mechanisms to support farmers in maintaining standards in biosecurity systems continue to hold great importance for PPC farmers.

During the outbreaks of AI, the government policy requiring the destruction of poultry within a $5-\mathrm{km}$ radius damaged the relationship between government officials and farmers compared with that preceding the AI outbreaks, because the farmers were afraid government officials would come and destroy poultry when their poultry on the farm fell ill. Thus, the farmers did not dare to report data to the officials. Consequently, the role of the officers in visiting to work with the farmers diminished. An obvious consequence was that the PPC in Nong Khai had low biosecurity systems in comparison with the PPC in Nakhon Phanom, because government officials were unable to visit and supervise farmers sufficiently, and the relationship between the officials and farmers was poor. Therefore, the solution is to create a process in which both government officials and farmers can take part.

Eco-heath is a concept linking the environment, socio-economics and health [21]. According to the findings of the current study, when the concept of eco-health is combined with the analysis of PPCs in Thailand, the results in the field are in accordance with the eco-health concept in terms of environment, because PPCs in the same area generally encounter problems in both air and water pollution. In addition, the incomes and lifestyles of farmers in these PPCs are involved with the effects on the relationship between government officials and the farmers when there are new outbreaks of AI on the farms or in nearby areas. Consequently, farmers are required to invest in additional disease prevention. Furthermore, when poultry die, the farming economy is affected. In addition, the related economics are also affected at the micro and macro levels. Moreover, outbreaks of diseases occurring in these poultry can infect humans. Therefore, it is evident that studies on all three dimensions will 
offer an aggregate perspective of the problems and enable thorough prevention of their potential impact, including recommendations for policy guidelines for the future.

\section{Conclusions}

The following three types of PPCs exist in Thailand: (1) PPCs raising chickens over fish ponds; (2) PPCs composed of egg-laying chickens managed in the form of cooperatives; and (3) PPCs in closed pens under contract with private sector companies. Following outbreaks of AI in each type of PPC, the disease prevention systems have been improved on the farms. The income earned from poultry products has increased, and some of the clusters have joined together in the form of cooperatives. Furthermore, there are poultry production systems under contract with private sector companies. However, having PPCs with a large number of farms in the same area has resulted in consequences, particularly air and water pollution, depending on the environments of each type of poultry production. Moreover, the government's policy for AI disease control by poultry destruction during outbreaks of the disease has damaged the relationship between farmers and government officials, thereby preventing the officials from visiting farms to promote poultry production and disease control methods as well as they should.

\section{Acknowledgments}

This research was funded by The International Development Research Center, Foreign Affairs, Trade and Development Canada (through the Global Health Research Initiative) and the Australian Agency for International Development.

\section{Conflicts of Interest}

The author declares no conflict of interest.

\section{References}

1. Christensen, S. The Role of Agribusiness in Thai Agriculture: Toward a Policy Analysis. TDRI Quart. Rev. 1992, 7, 3-9.

2. Borelli, A.; Ghobadi, N.; Otte, J.; Pfeiffer, D.; Roland-Holst, D. Policy Responses to the Threat of Highly Contagious Disease Originating in Domestic Animals: An Overview of Recent Experience with Avian Influenza; the Pro-Poor Livestock Policy Initiative; FAO: Rome, Italy, 2005; p. 4.

3. Heft-Neal, S.; Kahrl, F.; Otte, J.; Roland-Holst, D. HPAI Risk Reduction and Smallholder Poultry Supply Chains-The Case of Thailand. Controlling Avian Flu and Protecting People's Livelihoods in the Mekong Region; HPAI Research Brief/No. 14; International Food Policy Research Institute: Washington, DC, USA, 2009; pp. 1-4.

4. Tiensin, T.; Nielen, M.; Songserm, T.; Kalpravidh, W.; Chaitaweesub, P.; Amonsin, A.; Chotiprasatintara, S.; Chaisingh, A.; Damrongwatanapokin, S.; Wongkasemjit, S.; et al. Geographic and Temporal Distribution of Highly Pathogenic Avian Influenza a Virus (H5N1) in Thailand, 2004-2005: An Overview. Avian Dis. 2007, 51, 182-188. 
5. Verbiest, J.P.; Castillo, C.N. Avian Flu: An Economic Assessment for Selected Developing Countries in Asia; ERD Policy Brief No. 24; Asian Development Bank (ADB): Manila, Philippines, 2004; p. 1.

6. Rushton, J.; Viscarra, R.; Bleich, E.G.; McLeod, A. Impact of Avian Influenza Outbreaks in the Poultry Sectors of Five South East Asian Countries (Cambodia, Indonesia, Lao PDR, Thailand, Viet Nam) Outbreak Costs, Responses and Potential Long Term Control; TCP/RAS/3010; FAO: Rome, Italy, 2005; pp. 7-8.

7. Tiensin, T.; Chaitaweesub, P.; Songserm, T.; Chaisingh, A.; Hoonsuwan, W.; Buranathai, C.; Parakamawongsa, T.; Premashthira, S.; Amonsin, A.; Gilbert, M.; et al. Highly Pathogenic Avian Influenza H5N1, Thailand, 2004. Emerg. Infect. Dis. 2005, 11, 1664-1672.

8. Barbazan, P.; Thitithanyanont, A.; Misse, D.; Dubot, A.; Bosc, P.; Luangsri, N.; Gonzalez, J.P.; Kittayapong, P. Detection of H5N1 Avian Influenza Virus from Mosquitoes Collected in an Infected Poultry Farm in Thailand. Vector-Borne Zoonot. 2008, 8, 105-109.

9. NaRanong, V. Structural Changes in Thailand's Poultry Sector: Avian Influenza and Its Aftermath. TDRI Quart. Rev. 2008, 23, 3-10.

10. Heft-Neal, S.; Kahrl, F.; Otte, J.; Roland-Holst, D. Assessment of Smallholder Indigenous Poultry Producer Viability in Thailand; Mekong Team Working Paper No. 9; Department for International Development: London, UK, 2009; pp. 1-5.

11. Safman, R.M. The Political Economy of Avian Influenza in Thailand; STEPS Centre: Brighton, UK, 2009; pp. 5-24.

12. Prakarnkamanant, A.; Mastin, A.; Patanasatienkul, T.; Kasemsuwan, S.; Wongsathapornchai, K.; Chanachai, K.; Otte, J.; Pfeiffer, D. Quantitative Risk Assessment of HPAI Virus H5N1 Release via Cock Fighting Activities into the 1-km Buffer Zones Surrounding Compartmentalised Broiler Chicken Farms in Thailand; Mekong Team Working Paper No. 11; Department for International Development: London, UK, 2010; pp. vi-X.

13. Burgos, S.; Otte, J.; Metras, D.P.R.; Kasemsuwan, S.; Chanachai, K.; Heft-Neal, S.; Roland-Holst, D. Poultry, HPAI and Livelihoods in Thailand-A Review; Mekong Team Working Paper No. 4; Department for International Development: London, UK, 2008; pp. 24-33.

14. Aengwanich, W.; Intarakhamhaeng, M.; Wandee, J.; Nongbua, T.; Chaiyasak, S.; Srikot, P.; Thammasar, K.; Junsanitsri, N.; Sritongtuam, K.; Tawinwaang, T. Poultry Production Clusters (PPCs) After AI Outbreaks in Thailand: Past, Present and Future Direction. Int. J. Poultry Sci. 2012, 11, 541-550.

15. Plaen de, R.; Kilelu, C. From Multiple Voices to a Common Language: Ecosystem Approaches to Human Health as an Emerging Paradigm. EcoHealth 2004, 1, 8-15.

16. National Bureau of Agricultural Commodity and Food Standards, Ministry of Agriculture and Cooperative. Good Agricultural Practices for chicken breeder farm. Available online: www.acfs.go.th/standard/download/eng/GAP_chicken.pdf (accessed on 14 December 2014).

17. Wei, H.; Aengwanich, W. Biosecurity Evaluation of Poultry Production Cluster (PPCs) in Thailand. Int. J. Poultry Sci. 2012, 11, 582-588.

18. Wheeler, E.F.; Weiss, R.W.J.; Weidenboerner, E. Evaluation of Instrumentation for Measuring Aerial Ammonia in Poultry Houses. J. Appl. Poultry Res. 2000, 9, 443-452. 
19. Ritz, C.W.; Fairchild, B.D.; Lacy, M.P. Implications of Ammonia Production and Emissions from Commercial Poultry Facilities: A Review. J. Appl. Poultry Res. 2004, 13, 684-692.

20. Rylander, R.; Carvalheiro, M.F. Airways Inflammation among Workers in Poultry Houses. Int. Arch. Occup. Environ. Health 2006, 79, 487-490.

21. Charron, D.F. Ecohealth Research in Practice; The international Development Research Centre: Ottawa, ON, Canada, 2012; pp. 1-30.

(C) 2014 by the author; licensee MDPI, Basel, Switzerland. This article is an open access article distributed under the terms and conditions of the Creative Commons Attribution license (http://creativecommons.org/licenses/by/3.0/). 